\title{
O Movimento Estudantil de 1968 e as CiÊNCIAS Sociais
}

\author{
Lincoln de Abreu Penna ${ }^{1}$
}

\begin{abstract}
Resumo
Este artigo analisa o Movimento Estudantil entre os anos de 1964 e 1968, período em que os estudantes se constituíram em reduto de resistência à ditadura militar. Examina também o impacto e os desdobramentos que tais manifestações ocorridas dentro e fora das universidades provocaram especificamente na área de ciências sociais. Trata-se de uma análise na qual o autor presta um depoimento, uma vez que, à época, militou duplamente, na condição de estudante e presidente de entidade estudantil e de professor de sociologia em início de carreira.

Palavras-chave: Movimento Estudantil. Ciências Sociais. Ditadura.
\end{abstract}

\begin{abstract}
This article analyses the Student Movement from 1964 to 1968, a period in which students became a bastion of resistance to the military dictatorship. It also examines the impact and consequences that such demonstrations, occurring inside and outside the universities, provoked, specifically in the area of the social sciences. It is an analysis in which the author offers his own testimony, since at the time he had two activist roles, as a student and president of a student group, and as a professor of sociology at the beginning of his career.

Keywords: Student Movement. Social Sciences. Dictatorship.
\end{abstract}

${ }^{1}$ Professor do Programa de Pós-graduação em História do Brasil da Universidade Salgado de
Oliveira - UNIVERSO. 


\section{INTRODUÇÃO}

0 Movimento Estudantil (ME) foi o grande protagonista do ano de 1968, não tanto por seus méritos - e ele até os teve - mas pela inércia da sociedade civil que, aturdida diante da acelerada radicalização dos militares, assistia com um misto de preocupação e deslumbramento os filhos da classe média enfrentar a truculência do regime recém-instalado. Independentemente da avaliação do $\mathrm{ME}, \mathrm{o}$ fato de os estudantes terem se empenhado em denunciar os desmandos $\mathrm{e}$ as arbitrariedades de setores dominantes representou um dado importante no cenário político do país. E não foi só uma geração de estudantes, mas há de se ressaltar a presença de jovens, de um modo geral, nas artes, na literatura, teatro e cinema, além de profissionais liberais que se iniciavam em suas atividades. Todos, intelectuais e técnicos, destacaram-se em seus afazeres ao adotar formas as mais criativas e variadas de resistência à opressão. Desenvolveram constantes denúncias contra as práticas de violência da repressão, que se montava nos cenários mais obscuros do poder político com a conivência de muitas autoridades representativas do regime ditatorial imposto à nação brasileira.

Os acontecimentos de maio e junho daquele ano, no cenário político nacional e internacional, destacaram como protagonista os estudantes. Este fato, não tão inusitado assim, apresentou, contudo, duas características. Uma delas foi o grau de autonomia dessas ações em relação aos partidos políticos, cuja influência nos meios estudantis sempre existiu, particularmente sobre as suas lideranças. Mas 0 grau alcançado pela vanguarda estudantil daquela época transformou as demandas reivindicatórias muito acima de pleitos doutrinários das variadas organizações políticas e ideológicas existentes nos meios estudantis. À época, qualquer referência a essa autonomia de ação era vista com certa impertinência por parte dos cientistas sociais.

A outra característica consistiu na introdução da realidade brasileira nos cursos e pesquisas no campo das ciências sociais. Até aquela época, os cursos, além de serem essencialmente abstratos, discutiam questões nem sempre relativas à problemática brasileira. Não se tinha, a rigor, uma produção nacional das ciências sociais no Brasil senão esporadicamente. A pesquisa era pouco praticada como instrumento daprodução científicanessa área. Ademais, os incentivos institucionais públicos eram limitadíssimos, não havendo, na verdade, uma política nacional voltada para a investigação permanente. ${ }^{2}$ Mesmo os temas a respeito de reformas a

\footnotetext{
${ }^{2}$ A CAPES, concebida por Anísio Teixeira e criada em 1953, de Campanha passou mais tarde a

O Movimento Estudantil de 1968 E as CiênCias Sociais 
serem empreendidas no país, no conjunto das Reformas de Base, por exemplo, do governo Jango, a questão da produção do conhecimento não era ventilada pelos que sustentavam essas reivindicações.

Havia exceções nesse panorama basicamente livresco. Na Universidade de São Paulo (USP), a presença de professores estrangeiros, particularmente franceses na área de ciências sociais, acabou por introduzir um gosto pela pesquisa. Segundo o testemunho de Florestan Fernandes, entre meados dos anos de 1950 e meados dos 1960, "operou-se uma revolução na mentalidade dos professores e dos alunos das escolas superiores do País. A negligência pela pesquisa foi substituída pelo afã ardoroso de pesquisar - e todos dão vazão a esse afã pesquisando alguma coisa, não importa com que fito ou com que proveito" (FERNANDES, 1966, p. 209). A generalização não se aplicava, talvez fosse fruto de uma experiência vivida por um docente que acompanhava num centro que se tornou pioneiro nas ciências sociais o despertar da pesquisa científica.

Desse modo, e com base nessas duas características apresentadas até agora, o propósito deste artigo é o de discutir essencialmente tais proposições, a partir da experiência de aluno e professor - situações vividas nesse período de meados da década de 1960. É evidente que, se na primeira a percepção é imediata, pois se trata de uma constatação, na segunda característica sua apreensão só pode ser observada ao longo do tempo. Por esta avaliação, torna-se possível identificar a mudança ocorrida tanto nas práticas de nossos cientistas sociais quanto nos currículos acadêmicos, cujas mudanças levaram em conta o impacto causado pelas manifestações estudantis. Estas tiveram no 0cidente 0 mês de maio como clímax de tais intervenções estudantis no cenário político e institucional, mas que se estendeu por quase todo o segundo semestre daquele ano de 1968, em vários países, inclusive no Brasil. Neste, sem dúvida, o marco foi representado pela Passeata dos Cem Mil, realizada no dia 26 de junho na cidade do Rio de Janeiro.

Àépoca daqueles acontecimentos, era professor eestudante, pois jálecionava desde 1965, quando assumi uma turma de Normal numa escola particular para ministrar aulas de sociologia, e cursava a graduação de história, tendo, inclusive, presidido o DCE da UEG (Universidade do Estado da Guanabara) ${ }^{3}$, atual UERJ,

se denominar Coordenação; só bem mais tarde passou efetivamente a investir na preparação do pessoal docente de nível superior qualificando-os.

${ }^{3} 0$ estado da Guanabara foi criado quando da transferência da capital do Rio para Brasília. A cidade do Rio de Janeiro, então Distrito Federal, tornou-se a sede de mais um ente federativo da República. 
entre 1966 e 1967. Portanto, o testemunho que dou é legitimado por essas duas atividades que desenvolvi, razão pela qual além da característica da autonomia, certamente partilhada por outros analistas, a que se refere às mudanças nas ciências sociais foi por mim vivida em sala de aula. Tanto quanto possível, tentarei articular a análise daquela situação com a experiência de ter acompanhado de perto, e com muita intensidade, os momentos mais destacados das primeiras formas de contestação à ditadura militar no Brasil.

Atuando nas duas pontas do ensino, como docente iniciante e como estudante mais veterano, pude aquilatar o nível de insatisfação de uma geração inconformada no que diz respeito aos conteúdos programáticos e aos métodos de transmiti-los. Por outro lado, e afora essa questão, esbarrava-se com a superficialidade de um ensino que não se coadunava com o espírito renovador a atiçar as mudanças. Eu próprio era, nesse sentido, uma contradição ambulante, pois se de um lado questionava alguns mestres conservadores, como professor não me distinguia nem um pouco daqueles a quem me opunha como estudante. Talvez essa dupla militância aguçasse a minha percepção como profissional e me deixava incomodado na condição de alguém que reproduzia as aulas em moldes tradicionais movido pela insegurança comum a quem se inicia em uma carreira profissional.

Como testemunho, este ensaio se insere no contexto de uma reavaliação, cujas investigações e reflexões têm se multiplicado, mormente no campo da educação. A questão que se coloca presentemente é o oposto do que acontecia nos anos 1960, ou seja, enquanto naquela época era notória a defasagem entre um ensino tradicional e meramente conceitual nas ciências sociais e o crescente grau de contestação dos estudantes, agora se percebe uma produção acadêmica de certo vigor e uma apatia dos estudantes no que se refere às reivindicações relativas à boa formação profissional. Não me proponho a examinar esta questão, apenas registrá-la para uma eventual e futura análise.

\section{Movimento Estudantil e a Perspectiva REIVINDICATÓRIA}

0 recrudescimento do ME ocorreu já no ano seguinte ao Golpe de 64, depois de um primeiro momento de desarticulação em virtude do impacto e da repressão dos golpistas. Em fins de 1965, algumas entidades reorganizaram-se e começaram a se articular no eixo Rio-São Paulo e Minas Gerais, em especial. A 
própria UNE manteve as suas conferências e pôde realizar os seus congressos nos anos imediatamente subseqüentes ao Golpe. No ano de 1968, estava convocado um novo congresso a ser realizado no interior do estado de São Paulo, em Ibiúna, cujos congressistas foram impedidos de realizá-lo. Cercados pela polícia, foram presos. Vivia-se ainda a perplexidade de uma ação cuja derrota das forças progressistas aconteceu sem que ao menos se esboçasse alguma resistência diante dos grupos reacionários e conservadores. E o PCB sofreu desde os primeiros instantes fortes críticas pela conduta adotada pelos seus dirigentes, muitos de seus militantes foram os primeiros a sofrerem as conseqüências da onda repressiva de um regime que jamais escondeu o caráter anticomunista de sua orientação. Internamente, 0 partido conheceria um processo de dissidência que varreu principalmente o setor estudantil, mais sensível às críticas que se faziam na esquerda brasileira.

Em pouco tempo, duas tendências iriam se constituir no seio do ME. Uma delas derivava de certa forma dos comunistas abrigados ou não no PCB. Esta tendência, no entanto, se afirma fora da influência da orientação desse partido, pois adquire maior relevância com a liderança exercida, no Rio, por Wladimir Palmeira, dissidente, a exemplo de outras lideranças estudantis, do PCB. A tendência se caracterizava por dar ênfase às reivindicações estudantis, sem minimizar o quadro geral de luta contra a ditadura. Em outras palavras, a forma de se denunciar à ditadura principiava pela especificidade da pauta que dizia respeito às questões das universidades. Com isso, era possível se aglutinar forças no ME para transformá-lo num instrumento eficaz de combate à ditadura.

A outra tendência teve nos estudantes filiados a AP (Ação Popular) seu principal núcleo. Das lideranças, coube a Luís Travassos, em São Paulo, melhor representá-la nos tempos que se estendem de 1967 a 1968, quando o ME ganha as ruas. Priorizava a luta geral contra a ditadura e via com certo desprezo a importância, naquela quadra histórica do país, das reivindicações estudantis, dentro do espírito soixante huitard dominante na maior parte dos países que conheceram o surto rebelde comandado pelos estudantes contras as normas e leis em vigor. Esta posição passava com mais facilidade junto aos setores mais engajados do ME, constituído, em grande parte, por correntes que se opunham ao reformismo, pecha que se atribuía aos comunistas pecebistas e a todos que faziam restrições à radicalização política dos estudantes.

Essas duas tendências atravessavam as organizações políticas que se formavam em virtude de rachas havidos não somente no PCB, mas em outros 
partidos de esquerda, incluindo a AP, cujo sucedâneo atendeu pelo nome de APML, ao adotar a perspectiva marxista-leninista, não só na sigla como na prática. Por outro lado, essas duas tendências se enfrentariam nos encontros estudantis, sendo o maior deles e o mais esperado aquele que se reuniria em Ibiúna, já no ano de 1968. Ambas tinham por parte de suas principais lideranças, no entanto, uma forte restrição aos membros do partidão. Os militantes deste partido minguaram em número e em cargos nas entidades estudantis, seja pelo êxodo para as diversas organizações que surgiram entre 1966 e 1971, ou pelo fato de muitas das entidades terem assumido a condição de "livres", isto é, fora da burocracia universitária e suas normas. Dessa maneira, proliferaram os DCEs-livres, assim como os DAs (Diretórios Acadêmicos) ou CAs (Centros Acadêmicos) igualmente livres. Poucos mantiveram a condição de órgãos vinculados às estruturas universitárias sem prejuízo de sua inserção efetiva no ME.

0 DCE-UEG que presidi foi um desses casos. Não tinha sido objeto de intervenção por parte das esferas dirigentes da universidade e tampouco esteve alheio aos diversos momentos da luta estudantil. No Rio de Janeiro, no âmbito das escolas superiores, era o único com esse duplo reconhecimento, da parte da reitoria como da parte das lideranças estudantis à época. Pessoalmente, como presidente da entidade, tive ocasião de denunciar o arbítrio nas reuniões do Conselho Universitário, às quais comparecia independentemente das tarefas desenvolvidas no ME. Mais do que isso, ainda encontrava tempo para atuar na Sessão Juvenil do $\mathrm{PCB}^{4}$, cooptado que fui, precisamente em razão da fuga de muitas de nossas lideranças para outras correntes organizadas partidariamente ou não. Transitava, portanto, das esferas legais, mais ou menos consentidas até então, até às esferas mais clandestinas da vida política.

0 PCB tinha, na verdade, adotado uma posição ainda mais ampla. Orientou a elaboração de uma carta programática para o ME que se intitulou de FUP (Frente Universitária Progressista) ${ }^{5}$, da qual eu fui um dos signatários. Este documento foi apresentado por ocasião da Conferência da UNE em 1967 e causou fortes reações junto aos setores de ambas as tendências que disputavam a hegemonia dos estudantes mais engajados. Se a pecha de reformismo tornara-se

\footnotetext{
${ }^{4}$ Organismo criado pela direção do partido quando da dissolução da Juventude Comunista nos anos 1950 e encarregado de assessorar os dirigentes comunistas sobre questões relativas à política juvenil.

${ }^{5}$ A íntegra da Carta Programática da FUP foi publicada no livro de Poerner (1967).

O Movimento Estudantil de 1968 e as CiênCias Sociais 
lugar comum para essas tendências em relação aos comunistas do PCB, depois da divulgação da FUP não havia mais dúvidas. E essa caracterização de reformistas possuía naqueles tempos um conteúdo extremamente pejorativo.

0 que diferenciava a posição do $\mathrm{PCB}$ no $\mathrm{ME}$ em relação à tendência reivindicatória era o fato de os comunistas considerarem que os estudantes eram integrantes de uma ampla aliança de forças. Os partidários da tendência em São Paulo eram, entre outros, José Dirceu. Ele e Wladimir atribuíam aos estudantes uma posição mais vanguardista no seio dessas forças, que se batia contra a ditadura. Havia também uma notória diferença quanto aos integrantes dessa aliança. Para os comunistas do PCB, a aliança incluía liberais que manifestavam críticas ao regime.

Os que sustentavam a perspectiva autônoma no ME entendiam que a adesão de profissionais liberais, artistas e demais segmentos intermediários da sociedade civil, assimseposicionaramporqueperceberam quehaviaumdenominadorcomum - a luta contra a ditadura - e a identificação com as legítimas reivindicações dos estudantes. Sabiam que não estavam sendo usados e essa sintonia, com o ímpeto das lideranças estudantis, correspondia a um sentimento igualmente comum. A censura era utilizada como uma forma de silenciar e tolher a criatividade dos que não podiam prescindir dessa faculdade. E a disposição de resistir à censura ajudou em muito à mobilização de categorias inteiras na imprensa e nas artes, setores mais afetados pelos maus-humores dos censores de plantão.

0 assassinato do estudante Edson Luís, no Restaurante do Calabouço, semanas antes do grande protesto que foi a Passeata dos Cem Mil, não só atiçou ainda mais a disposição das vanguardas estudantis contra a ditadura, como estabeleceu um nexo de causa e efeito entre as reivindicações estudantis e a intolerância do governo em relação aos opositores do regime. Este nexo ressaltava a importância da questão estudantil, logo da primazia do problema reivindicatório sobre outros problemas. A própria ação mobilizadora com vistas à convocação dos participantes da referida passeata centrava-se na justeza dessas reivindicações, contrariadas por um governo insensível diante da gritante necessidade de voltar-se para a formação das futuras gerações. Os teatros do Rio, as redações dos principais jornais da cidade e as entidades defensoras das liberdades, tais como a $\mathrm{OAB}, 0$ Clube de Engenharia, e os sindicatos, foram também instados a comparecer à manifestação em defesa dos estudantes.

Em todos esses segmentos, a avaliação era a de que se tratava de uma justa manifestação dos estudantes em defesa de seus direitos e de seus pleitos. 
Por mais que se admitisse que a atitude estudantil implicasse num repúdio ao regime ditatorial, não havia como centrar o comentário acerca da especificidade do gesto dos estudantes. 0 reconhecimento da autonomia estudantil em face da conjuntura dominantemente política e ideológica atravessava essa relação com a sociedade civil organizada. A própria tradição da UNE, mesmo nos momentos em que os problemas políticos e institucionais foram determinantes, fortaleciam essa perspectiva autonomista sem prejuízo de sua conexão com o quadro mais geral da sociedade. Afinal, o enfrentamento dos estudantes dessa vertente com a política educacional do governo era, objetivamente, uma forma de estabelecer essa conexão reclamada pelos seus críticos.

E essa percepção do problema educacional como um instrumento de contestação do regime se dava no contexto de uma realidade marcada pelo Acordo MEC-USAID, cuja denúncia propiciava exatamente essa ponte para a caracterização de um regime disposto a submeter o país a estratégias no mínimo duvidosas na área da educacional ${ }^{6}$. Assim, discutir essa questão não era se omitir da situação política dominante; ao contrário, era dar um caráter mais concreto e viável às lutas estudantis, da mesma forma que os operários faziam em relação às suas reivindicações salariais. Essa compreensão era de grande importância para que se tivesse uma posição mais conseqüente no processo de lutas que se configurava. Longe de ser uma evasão da realidade, a perspectiva autonomista deixava de lado os aspectos meramente retóricos da luta contra o "imperialismo e seus agentes internos" para atacar frontalmente a orientação dos governos militares em face do projeto educacional para o país.

\section{O ME e a Perspectiva da Derrubada da Ditadura}

A tendência que se opunha à reivindicatória era a que acentuava o papel dos estudantes como um dos grupos de vanguarda contra a ditadura. Neste sentido, essa corrente se achava mais próxima da maior parte da rebeldia estudantil que tomava conta de capitais européias, como a que se expressava em Paris e Berlim, sob a liderança de Cohn Bendit. Esse vanguardismo se expressava na convicção de que caberia aos estudantes um lugar destacado diante da nova ordem que se julgava estar em condições de acontecer. Seus ideólogos assumiam ares de revolucionários dos novos tempos.

\footnotetext{
${ }^{6} 0$ Acordo resultou na reforma do ensino. 0 curso superior passaria a ser designado de terceiro grau. Previa assessoramento norte-americano e a obrigatoriedade do ensino da língua inglesa. 
Derrubar a ditadura ou derrotar a ditadura? Essas duas palavras de ordem resumiam as correntes que disputavam a massa estudantil, nas entidades ou nas ruas. Na primeira, a idéia de se considerar o ME como uma força capaz de empreender essa tarefa provocava divisões quanto à forma de se operar esse desideratum. Afinal, que alianças convinham que se estabelecesse com esse propósito. E aí as variações eram múltiplas, todas, contudo, assinalando o ME como tendo um papel saliente nesse processo de queda do regime. Para seus adeptos, não era o caso de se discutir o objetivo, mas sim os meios para efetiválo. Se as esquerdas, no geral, filiavam-se em torno da primeira das palavras de ordem, o PCB sustentava a que preconizava a derrota do regime. De certa forma, a primeira acabara por reunir as duas tendências que disputavam o ME. 0 problema era exatamente o da amplitude das alianças. A idéia de derrota sugere a prevalência da política sobre as ações de confronto. Derrotar é isolar de tal forma o regime que sua sobrevivência não demoraria muito tempo.

No que se refere às formas de luta, as diferenças não eram tão distintas assim. Havia a crença de que a greve estudantil, desde que organizada, representava em si uma denúncia do regime, além de tornar pública a posição do ME diante da permanente intransigência do MEC e dos governos militares de um modo geral. As intervenções nos DAs e DCEs por parte das reitorias fez proliferar uma atitude de evasão da realidade legal. Além disso, já começavam os recrutamentos de estudantes para as organizações revolucionárias saídas das dissidências de modo a levar a contarem com militantes que provassem determinação nas lutas estudantis.

A lógica dessa concepção consistia em centralizar a luta pelo fim da ditadura em razão da total descrença da possibilidade do regime atender minimamente as questões relativas às demandas estudantis, bem como a qualquer tipo de reivindicação. Para os seus representantes, não havia como pretender a obtenção de concessões de um regime político avesso a qualquer melhoria qualitativa do ensino, tendo em vista a prioridade que dava seus dirigentes no que respeita às áreas técnicas, uma vez que se tratava de uma visão de "grande nação" a empurrar projetos eivados de megalomania, típicos de militares ciosos de converter o país numa instância do subimperialismo continental. Logo, não passava de ledo engano acreditar em medidas concretas para o bem das diversas áreas educacionais por parte dos homens que dirigiam a política educacional dos governos militares. 
Assim, a derrubada da ditadura abriria caminho para a realização das aspirações do povo brasileiro. Conviver com o regime sem desalojá-lo do poder era uma atitude desprovida de qualquer análise política mais séria. Há que acrescentar que essa concepção se fortalece no instante em que as dissidências engrossavam as novas organizações políticas e vencia as disputas em numerosas entidades do ME. A própria intransigência do regime só reforçava ainda mais essa convicção da necessidade de se partir para o confronto com as forças que o sustentavam. Em diversos outros campos, como o da música, por exemplo, assistia-se nos festivais da canção a boa receptividade de letras, como as do compositor Geraldo Vandré em "Caminhando ou Pará não dizer que não falei de flores" sobre outras muito mais melódicas, a exemplo de "Sabiá", de Tom Jobim e Chico Buarque de Holanda, que, não obstante, eram recebidas com certo desdém.

Sem dúvida, a escalada da repressão e do arbítrio acabara por estimular também a escalada contrária, a da resistência de formas mais ousadas de setores combativos da sociedade civil. E é claro que entre os estudantes caberia um lugar não desprezível para que essa sensação de dever cumprido na luta contra a ditadura atravessasse o portão da legalidade e se expandisse no perigoso e incerto campo da clandestinidade. A política de conta-gotas, do terreno paciente da "guerra de posição" não entusiasmava os mais irados com o recrudescimento da repressão e da tortura. 0 enfrentamento continuaria mesmo nas manifestações estudantis que ganhavam também formas mais contestadoras e violentas. Parecia que se tratava de um ensaio geral com vistas a uma luta mais ampla e maior contra a ditadura.

Por outro lado, essa concepção revelava certo desprezo pelas instituições universitárias. Acreditavam seus membros que a resolução dos problemas de cunho acadêmico e pedagógico, bem como os de natureza própria da política educacional passava antes pela derrubada do poder político instalado pelo regime militar. Pecavam, no entanto, pela ausência de análises que justificassem ou pelo menos explicassem essa conduta refratária às teses que eram acolhidas pelas correntes que a essa concepção se opunham. Tomavam a ditadura como um fato de origem e essência inquestionáveis e, portanto, passível de acolher a atitude que inspirava a maioria de seus integrantes, cujo processo os levaria ao confronto direto com 0 regime e 0 abandono total da pauta relativa à questão estudantil.

0 engajamento dos estudantes atraídos por essa concepção de confronto direto com a ditadura impôs, em muitos casos, o abandono dos cursos nas universidades e, no caso de engajamento político nas organizações surgidas a partir 
da elaboração dessa concepção, também das relações familiares e dos círculos de amigos. Tal conduta acabou por esgarçar os integrantes dessa concepção, seja em razão da atomização das organizações alternativas de esquerda, cujo número proliferou num dado momento, seja pela clandestinidade imposta por essa decisão de confrontar-se objetivamente com o regime. Isolados os combativos quadros que vão se dedicar à luta armada, egressos do ME não lograram senão experiências amargas e a sensação de um dever cumprido em face da escalada de um regime que não hesitará em empregar métodos de terror para intimidar seus oponentes. Mas, a primeira fratura do elo do ME com a sociedade foi a retirada das ações estudantis da pauta dos jornais, que normalmente davam cobertura às manifestações estudantis.

\section{O impacto nas Ciências Sociais}

Os debates paralelos em meio às revoltas estudantis no ocidente produziram uma efervescência intelectual não desprezível. E irão influir em médio prazo nas modificações que os cursos de ciências sociais passarão a conhecer. Novas referências de autores contemporâneos passaram a conviver nas salas de aula e fora delas, talvez mais nestas do que naquelas, pelo menos num primeiro momento. Assim aconteceu com Herbert Marcuse, um dos integrantes da Escola de Frankfurt', que foi um dos filósofos cuja obra acabou sendo disseminada para o resto do mundo. Ícone de grupos radicais dos movimentos de contestação na Europa e fora do velho continente seus pronunciamentos a favor das manifestações estudantis repercutiam. Os enfrentamentos das forças da ordem com os insurretos nas praças e ruas de uma Europa perplexa com a determinação dos estudantes e em alguns casos com a instauração do caos urbano tornavam Marcuse uma figura que destoava nos ambientes acadêmicos, ainda profundamente presos aos ritos tradicionais. Homem de 70 anos com seus cabelos brancos que impunham respeito, Marcuse demonstrava que a rebeldia não estava restrita aos jovens. Para ele, a rebeldia não tem idade.

Mas havia quem censurasse o caráter violento dessas manifestações por julgarem impróprias para a respeitabilidade das esquerdas, que mantinham àquela altura, em muitas sociedades européias, boas perspectivas eleitorais, principalmente na Itália. Neste país, o projeto do PCI e o seu desejo de construção de um modelo socialista europeu levavam em consideração as tradições culturais

${ }^{7}$ Sobre esta escola, ver Slater (1978). 
do Ocidente. Era o Eurocomunismo. Muitos militantes comunistas se encantaram com essa versão mais livre do socialismo banhado de liberdade e de compromisso histórico com forças democráticas, que na Europa Ocidental resgatava a aliança com a democracia cristã italiana e, sobretudo, a social-democracia européia, além de atrair os socialistas não leninistas.

0 filósofo italiano Antonio Gramsci passou a ter sua obra consumida como nunca, afinal o impulso dos movimentos sociais agitando bandeiras libertárias não se coadunava com a rígida disciplina soviética avessa a tais manifestações. Dessa maneira, os conceitos de guerra de posição e de guerra de movimento, que Gramsci tomou emprestado das refregas da Primeira Guerra Mundial para aplicá-las à política, passaram a povoar os debates em torno dos processos sociais e políticos. Na primeira dessas guerras, o que importa é estabelecer a prevalência dos expedientes táticos, ao passo que na outra a prepondera à ofensiva militante com base numa retaguarda capaz de dar sustentação à operação. Contra esse modo de se cogitar, a ação política não demoraria e uma nova concepção surgiria nesse que era um horizonte revolucionário. Trata-se do Foquismo, cuja autoria intelectual deveu-se ao filósofo francês Régis Debray. Mais do que a organização, mais do que as táticas empregadas, impunham-se, de acordo com o manual revolucionário de Debray, a criação de focos revolucionários, baseado na sentença proferida por Ernesto Che Guevara segundo a qual o dever de um revolucionário é fazer a revolução. Estava, assim, aberta a temporada das grandes discussões políticas e doutrinárias acerca da revolução que todos esperavam.

No que tange à estrutura curricular e os seus conteúdos, os programas das disciplinas de sociologia, Introdução à Sociologia ou Sociologia Geral, nomes mais empregados para a matéria de iniciação dos estudantes nesses estudos, eram marcadamente conceituais. Discutiam-se os conceitos da matéria a partir da visão de seus fundadores e, quando muito, aludiam-se às teorias que as inspirara como campo de estudos particular. Os mestres mais eruditos ainda percorriam com exuberância as diversas contribuições a registrarem momentos de maior inflexão nos debates que se sucediam na esfera das reflexões teóricas, exclusivamente situadas na esfera dos embates dessa natureza ocorridos na Europa com alguns respingos em certos ambientes acadêmicos norte-americanos. Nenhuma aplicação desses conceitos à realidade do país, de modo a tornar estéril esse aprendizado.

Lembro-me que, quando lecionei Sociologia para o referido curso Normal, elaborei um programa convencional fruto da insegurança de quem se iniciava 
no magistério, mas também do rito comum aos professores empenhados em reproduzir conteúdos programáticos devidamente referendados pelas instâncias superiores. Muito embora o material humano do curso propiciasse discussões a respeito de temas que possivelmente despertassem mais o interesse daquelas alunas, não atinava para 0 alcance positivo de uma decisão que deixasse de lado aquele programa formal. As leituras que fazia tanto dos clássicos da sociologia quanto das investidas mais originais nesse campo não me motivaram a recorrer a expedientes mais ousados. Havia, assim, uma dualidade um tanto quanto esquizofrênica, pois era um indivíduo em sala de aula completamente distinto do indivíduo que agia fora do ambiente escolar.

Não tenho dúvidas de que a década de 1960 representou um divisor de águas entre tradição e modernidade no Brasil, não importa a densidade maior ou menor que se dê a esses vocábulos. 0 fato é que as mudanças comportamentais ocorreram rapidamente durante a vigência desse período relativamente curto de tempo. E o ano de 1968 foi simbólico no sentido de representar um momento especial dessa transição do Brasil tradicional para o Brasil moderno, do agrário para 0 urbano. Abriram-se com 1964, inicialmente, e depois em 1968, duas possibilidades. Na primeira, vislumbrava-se a perspectiva de um caminho de emancipação econômica com grandes dividendos sociais e políticos, perspectiva esta negada pelos autores do golpe; e, em seguida, a que se vislumbrou com 0 episódio da passeata, não tanto no sentido de possibilitar mudanças de estruturas, mas de se pensar nos rumos que o país enfrentava: evoluir para um regime de força ou percorrer um caminho democrático e libertário.

Os cursos de ciências sociais tiveram suas matrículas incrementadas durante a virada das décadas de 1950 e 1960, especialmente no Rio de Janeiro, e mais particularmente na então Faculdade Nacional de Filosofia da Universidade do Brasil, hoje UFRJ. Neles, os conteúdos eram dominantemente teóricos. As questões metodológicas e epistemológicas não ocupavam espaços e, salvo por iniciativa de alguns professores mais ligados à pesquisa e às novas contribuições sociológicas e antropológicas de outros centros universitários mais densamente voltados para a investigação, não era muito comum a presença dessas questões. Professores como Costa Pinto, Djacyr Menezes e Álvaro Vieira Pinto eram humanistas ilustrados, conferencistas de mão cheia. Outros, como o ultraconservador Hélio Vianna e Eremildo Luiz Vianna, fiel bajulador do regime militar, eram transmissores de conteúdos programáticos factuais. 0 primeiro desses professores era catedrático de História do Brasil, cultivava o conhecimento factual a exigir a memorização 
do conteúdo descritivo de seu livro. 0 outro, era catedrático de História Antiga e Medieval e exibia uma erudição discutível. Ambos se refugiavam numa perspectiva formal descolada da realidade social e dos novos horizontes do conhecimento.

0 professor Costa Pinto foi o primeiro daquele corpo docente da Faculdade Nacional de Filosofia a desenvolver em ensaio uma avaliação sobre a situação das ciências sociais. Publicado sob forma de um pequeno opúsculo, discorre sobre o crescimento e os desafios dessa área de conhecimento diante dos problemas inerentes à sociedade brasileira. Elegantemente vestido, portando óculos escuros e trajes dominantemente claros, como ternos brancos, o professor baiano foi um dos perseguidos pela irrupção da ditadura e se exilou, como muitos dos seus colegas em face da escalada da repressão nas universidades brasileiras. Com a caça às bruxas, prevaleceu a mediocridade e a atitude de subserviência, com danos terríveis para as novas gerações já divorciadas do espírito crítico e voltadas exclusivamente para a titulação e o mercado de trabalho. 0 questionamento dos currículos deu lugar à aceitação tácita de conteúdos curriculares impostos à revelia dos estudantes.

Mas as matérias constantes do currículo dos cursos de ciências sociais até meados da década de 1960 eram basicamente restritas ao seu núcleo básico e eram distribuídas em três grandes áreas: sociologia, antropologia e ciência política. Cada qual comportava segmentos ou disciplinas complementares. Não havia muitas opções como matérias eletivas para livre escolha dos alunos. Essas opções só se tornaram mais freqüentes a partir da reforma que introduziu mais tarde o sistema de créditos, hoje em dia comum a quase totalidade dos cursos nas universidades brasileiras. E, ainda dentro dessa estrutura original, as disciplinas básicas eram orientadas pelos professores catedráticos e a boa ou má condução desses cursos dependia muito da personalidade desses catedráticos.

Uma das reivindicações dos estudantes, anterior ao golpe de 64, era precisamente o fim da cátedra, entre outros itens que compunham a pauta do ME nos tempos em que a UNE demonstrava força e prestígio junto às autoridades governamentais. 0 fim do regime de cátedra estava muito associado ao comportamento desses professores, em geral reacionários ou pelo menos excessivamente conservadores para permitir mudanças pedagógicas ou metodológicas e menos ainda programáticas. Detendo um poder de mando na condução dos cursos fundamentais, os catedráticos possuíam a faculdade de cooptar seus assistentes e colaboradores à revelia de conselhos ou critérios institucionais. Assim, reativos a qualquer demanda que pleiteasse algum tipo de 
alteração na relação entre mestres e estudantes, não se observara até meados dos anos 1960 quaisquer possibilidades de alteração nesse quadro.

As pesquisas sociológicas e antropológicas eram escassas antes da década de 1960. As abordagens nessas áreas ficavam por conta de reflexões eruditas de nossos intelectuais que atuavam na área de ciências sociais. Geralmente bacharéis de Direito, esses precursores da produção de livros de referência nas ciências sociais eram dotados de uma cultura geral bem sólida e de preocupações com os rumos do país. Assim, lá pelos idos da década de 1930, foram eles os responsáveis por obras que até que integram o patrimônio historiográfico brasileiro, tais como as de Sérgio Buarque de Holanda, Gilberto Freyre e Caio Prado Júnior, para citarmos os mais recorrentes nomes dessa safra que antecede a pesquisa científica continuada.

Era comum os profissionais da área de ciências sociais se referirem aos demais especialistas das áreas de ciências exatas e biológicas como cientistas ou simplesmente pesquisadores, como se a eles não coubessem também essas designações. Na universidade brasileira, eles tinham por hábito o trato da teoria com a pesquisa aplicada, fato que não era praticado nas ciências sociais. A propósito, na então Universidade do Brasil, existia um Instituto de Ciências Sociais independente do curso de Ciências Sociais, onde se desenvolviam pesquisas descoladas da formação acadêmica dos futuros profissionais dessa área. Esse divórcio entre a teoria e a prática só foi deixado de lado com a reforma universitária e o bom aproveitamento dos recursos para o fomento à pesquisa por parte de nossos colegas das ciências sociais. Foi o regime militar, mais desejoso de financiar pesquisas nas áreas técnicas e tecnológicas, em função de acalentarem um projeto de "grande nação", que acabou por estimular as pesquisas sociológicas e antropológicas.

Mas a atitude em face do papel das ciências sociais teve, senão um momento de inflexão importante, pelo menos uma manifestação decidida, que marcou consideravelmente os profissionais da área. Refiro-me ao artigo de Florestan Fernandes intitulado Sociólogos: Os Novos Mandarins? Traduzido do inglês quando de sua publicação em 1969 pelo Departamento de Sociologia da Universidade de Toronto, edição mimeografada. Pequeno, este artigo é categórico no que diz respeito ao lugar que deve ser ocupado pelos que exercem as atividades nesse campo. Destaque para a passagem na qual o sociólogo paulista diz:

0 essencial é uma clara compreensão de que a quebra do isolamento e a decisão de escolher entre soluções alternativas não têm sentido se o sociólogo faz isso como pura atitude intelectual. 0 envolvimento deverá ser antes 
crítico e militante. 0 sociólogo possui vários papéis, como deve ter todo cientista social, e esses papéis devem ser dinamizados em todos os níveis da vida social, em benefício da liberdade, da igualdade social e da consciência social, da sociedade e de sua civilização, e da humanidade (FERNANDES, 1974, p. 144).

Assumir uma atitude de investigação não-isenta ou neutra feria de morte a concepção até então dominante segundo a qual não caberia ao cientista social se imiscuir das questões políticas de sua época. Florestan Fernandes não só desmistificava essa posição como se definia como "sociólogo e socialista". E continuava: "Não pretendo para mim um terceiro caminho: pois me oponho, de modo claro e decidido, ao isolamento dos cientistas sociais e à neutralização das ciências sociais, em matérias que sejam vitais para a evolução futura e as transformações da civilização atual". Essa atualidade no Brasil passava, entre outras coisas, por medidas que viessem a acelerar o progresso social, o que passava pelas mudanças estruturais da sociedade brasileira e o arcaísmo dos projetos de suas classes dominantes. Dessa maneira, mesmo sob o tacão da ditadura instaurada, Florestan Fernandes introduzia uma nova perspectiva no que se refere ao trato acadêmico. Era uma questão que ficara durante muito tempo apenas na esfera da consciência de alguns cientistas sociais que temiam a retaliação no caso de explicitarem essa atitude mais ousada, segundo os padrões de uma ciência social comportada e formal.

Não fora a tensão criada pela ação arbitrária da ditadura e o anseio de uma geração de intelectuais despertados pelas questões suscitadas na época das reformas de base do governo Jango, talvez a manifestação de Florestan Fernandes não passasse de um mero registro sem grandes conseqüências. Afinal, assim aconteceu, no passado, com Manuel Bonfim, cuja obra de análise e denúncia de uma realidade latino-americana só foi "descoberta" muito tempo depois de tê-la feito circular". Autores malditos, esquecidos ou silenciados, não foram tão poucos assim, mas a conjuntura na qual se inseriu o texto afirmativo de Florestan Fernandes foi fundamental para a afirmação das ciências sociais no Brasil. Ainda que a tradição ainda estivesse alicerçada na erudição humanista, a escola sociológica paulista, da qual Florestan era um dos expoentes, firmava o princípio da pesquisa da realidade brasileira com o engajamento na solução dos problemas nacionais.

\footnotetext{
${ }^{8}$ Refiro-me ao livro América Latina, males de origem (1993), publicado em sua primeira edição no ano de 1905, só reeditado em 1931.
} 
A idéia de revolução era uma constante entre os intelectuais e formadores de opinião. Recordo-me de expressões como "revolução na educação" de Anísio Teixeira, ou de "revolução das massas" de Álvaro Vieira Pinto, professor da Faculdade de Filosofia da Universidade do Brasil e membro destacado do ISEB (Instituto Superior de Estudos Brasileiros). Todos se debruçavam sobre a realidade pouco investigada, mas objeto de interesse ainda não transformado em assunto curricular, salvo na perspectiva de alguns dos mais arrojados cientistas sociais, que esbarravam, contudo, na resistência de velhos padrões conservadores dos detentores de cátedras na universidade brasileira. Essa atmosfera iria criar um ambiente de temor nas classes dominantes e de forte expectativa junto aos setores progressistas e renovadores, dentro e fora da academia. É nesse vácuo entre a tradição e a modernidade que se insere a atuação dos estudantes, bem como a lenta mudança nos conteúdos disciplinares dos cursos de ciências sociais.

A introdução da sociologia no curso de Direito da Universidade do Brasil fora mais do que uma novidade. Ela significou a interação ausente com a tal realidade brasileira reduzindo, de certa forma, o conteúdo curricular desse curso de sua formalidade excessivamente técnico-jurídica. É evidente que no caso em tela, a presença do professor Evaristo de Moraes Filho foi decisiva, já que ele acumulava à época as cátedras de Direito do Trabalho e de Sociologia em duas unidades distintas da Universidade do Brasil ${ }^{9}$. Era a confirmação de que os estudos acerca da realidade brasileira haviam se tornado de tal maneira ponderáveis, que contra uma sisuda congregação, como a do direito, foi possível fazer passar essa inovação, de modo a fortalecer a presença da área de ciências sociais na universidade brasileira que detinha um papel de ponta no ensino superior, não só no Rio de Janeiro como no país.

A direita, assanhada com o golpe, associava sociologia a socialismo, e, a julgar pelo que escrevera Florestan Fernandes, com um certo sentido lógico, pois examinar a realidade brasileira era posicionar-se necessariamente sobre as questões que despontavam como problemáticas. Claro que, na visão de Florestan, essa relação guardava coerência, pois era impossível tratar esses problemas como algo natural e não como problemas construídos historicamente, à luz de um projeto conservador e arcaico. Mas a alusão a essa associação era feita para

\footnotetext{
${ }^{9}$ Como professor e intelectual respeitado por sua vasta cultura, é autor de um dos clássicos das ciências sociais, o livro O problema do sindicato único - seus fundamentos sociológicos (1978), publicado originalmente em 1952. Nesta obra, ele sintetiza bem as duas vocações, a de professor de Direito Trabalhista e de Sociólogo.
} 
desqualificar a sociologia e demais ciências sociais consideradas instrumentos de proselitismo da esquerda. Mesmo a sociologia de Comte, com a sua estática e dinâmica, dentro de uma rejeição às mudanças sociais e estruturais consideradas como "patologias sociais", era colocada de lado, na medida em que despertavam interesses que não interessavam aos ideólogos da direita. Assim, a sociologia era vista como um estudo incômodo.

A propósito do conceito de patologia social, Alberto Guerreiro Ramos, um dos fundadores do ISEB, escrevera num texto de 1957 e publicado por esta entidade vinculada ao MEC, um trabalho intitulado Ideologias e Segurança Nacional, no qual conclui dessa maneira: "A ideologia não é um fenômeno de patologia social; existe e existirá, necessariamente, em toda sociedade porque o pensamento e a conduta do homem não podem superar suas limitações históricas." (GUERREIR0 RAMOS, 1957, p. 49-50). Portanto, antes mesmo das mudanças provocadas pelas agitações estudantise pelas mudanças comportamentais havidas ao longo da década de 1960 do século passado, já existia um pensamento crítico e profundamente comprometido com a realidade social e seus fundamentos históricos.

A subversão passara, nos tempos da ditadura, a ser a mais moderna forma de patologia a ser combatida. Afinal, o fracasso da revolução brasileira como projeto alternativo das forças de esquerda abrira caminho para a consagração da "Revolução Democrática de 31 de Março de 1964". Apropriavam-se, assim, dois vocábulos atribuindo-os valores reacionários. Era a revolução de contenção em face da iminência de mudanças estruturais, de um lado, e a democracia como valor relativo à ordem. Todavia, longe de reduzir o interesse pelos estudos sociológicos e históricos, essa distorção da realidade estimulou ainda mais o gosto pelas ciências sociais.

Os números atestam isso. Logo após o golpe, um dos problemas enfrentados pela direção das faculdades que compunham a Universidade do Brasil era 0 dos excedentes, isto é, vestibulandos aprovados que, no entanto, não podiam ser matriculados em razão das vagas, cujo número estava aquém da demanda crescente. E o curso de Ciências Sociais foi um dos que tiveram mais excedentes, em razão do crescimento que vinha experimentando. 0 que comprova 0 interesse despertado pela conjuntura que, não obstante adversa, exercia certo fascínio e não deixava de instigar a reflexão da realidade. E esse fato é mais relevante se considerarmos que não se tinha ainda a profissionalização dos sociólogos, por exemplo. Na ausência de uma tradição de pesquisa científica na área, os formandos 
em Ciências Sociais tinham como alternativa o magistério, no qual disputavam com professores de História e Geografia um mercado de trabalho que a função de sociólogos negava aos que se licenciavam nessa área do conhecimento.

A reforma universitária, no caso da área de Ciências Sociais, integrou 0 curso e o Instituto de Ciências Sociais. Mesmo sem uma forte tradição da pesquisa científica, o instituto desenvolvia projetos de pesquisa ausentes no âmbito do curso, meramente instrumental no sentido de formar bacharéis da área. Mas a fusão não propiciou, em curto espaço de tempo, o incremento da pesquisa quando da criação dos institutos integrados aos cursos. Só bem mais tarde, e com uma política mais generosa dos órgãos de fomento à pesquisa, tais como o CNPq, Capes e Finep, e, sobretudo com o advento dos cursos de pós-graduação, é que a pesquisa foi introduzida como uma atividade corrente nos meios acadêmicos.

Essa mudança não está, contudo, apenas no maior fomento à pesquisa. Há de se considerar uma outra mudança mais relevante até do que esta, muito embora de caráter subjetivo. Refiro-me ao momento em que prevaleceu entre os docentes, em especial, a idéia segundo a qual o mais importante não era o que os mestres faziam nas universidades, mas o que produzem, e daí colocar esse produto a serviço da sociedade. Para tanto, foi preciso implantar os regimes de trabalho continuados, de tempo integral, eliminando-se gradativamente os tempos parciais e a figura ainda presente no setor privado dos horistas, docentes a atuarem somente como transmissores de conhecimento sistematizado e sem projetos de pesquisa. Em função dessa mentalidade que se constrói pouco a pouco, surgiram as publicações acadêmicas, periódicas ou não, que têm propiciado uma maior interação entre os docentes.

A conclusão de um depoimento sempre implica numa relação com 0 tempo. E o que presto com base neste relato se dá no momento em que os 40 anos do emblemático ano de 1968 acontecem, o que sugere reflexões acerca do papel dos estudantes e dos cientistas sociais e de seus compromissos com os rumos do país. Mais do que nunca, está na ordem do dia o projeto de construção de uma sociedade digna de seus cidadãos, e a recuperação de uma bandeira desfraldada por uma geração que lutou por ideais não realizados por completo até hoje. Ideais altruísticos, nem sempre bem encaminhados e convincentes para a maioria da população, mas seguramente pleno de generosidade. 


\section{REFERÊNCIAS}

BOMFIM, Manoel. América Latina, males de origem. [1ª ed., 1905]. Rio de Janeiro: Topbooks, 1993.

FERNANDES, Florestan. Sociólogos: Os Novos Mandarins? Debate \& Crítica, n. 4, São Paulo, nov. de 1974.

1979.

.Apontamentos sobre a "Teoria do Autoritarismo". São Paulo: Hucitec,

GUERREIR0, RAMOS, Alberto. Ideologias e Segurança Nacional, coleção Textos brasileiros de sociologia, Rio de Janeiro: MEC/ISEB, 1957.

MARCUSE, Herbert. A Ideologia da Sociedade Industrial. Tradução Álvaro Cabral. Rio de Janeiro: Zahar Editores, 1968.

. Eros e Civilização. Tradução Álvaro Cabral. Rio de Janeiro: Zahar Editores, 1968.

MORAES FILHO, Evaristo de. O problema do sindicato único: seus fundamentos sociológicos [1ª ed., 1952]. São Paulo: Alfa-Omega, 1978.

PENNA, Lincoln de Abreu. A Auto-História: a intervenção no social. Rio de Janeiro: E-papers, 2005.

POERNER, Arthur. O Poder Jovem, Rio de Janeiro: Editora Civilização Brasileira, 1967.

SLATER, Phil. Origem e Significado da Escola de Frankfurt: Uma perspectiva marxista. Tradução de Alberto Oliva. Rio de Janeiro: Zahar Editores, 1978.

TOLEDO, Caio. ISEB: Fábrica de Ideologias. São Paulo: Ática, 1977. 